\title{
Ecological studies on a population of the water snake Grayia smythii in a rainforest swamp of the Niger Delta, Nigeria
}

\author{
Godfrey C. Akani ${ }^{1}$ \& Luca Luiselli ${ }^{2}$ \\ 'Department of Biological Sciences, Rivers State University of Science and Technology, P.M.B. 5080, Port \\ Harcourt, Rivers State, Nigeria, e-mail:rsust@alpha.linkserve.com; ${ }^{2}$ Centre of Environmental Studies \\ "Demetra", via dei Cochi 48/B, I-00133 Rome, Italy; F.I.Z.V., via Olona 7, I-00198 Rome, Italy; and Mu- \\ nicipal Museum of Natural History, piazza A. Frezza 6, I-00030 Capranica Prenestina, Rome, Italy, email: \\ lucamlu@tin.it (corresponding author)
}

Keywords: Grayia smythii, Colubridae, snakes, ecology, Nigeria

\begin{abstract}
The ecology of the water snake, Grayia smythil (Reptilia: Colubridae) occurring in a seasonal rainforest swamp of the Niger Delta (southern Nigeria) was investigated between December 1998 and March 2000. Females and males were similar in body sizes (SVL) and head sizes, but males had tails significantly longer than females. The diet was constituted only by frogs and fish. The major prey type was Xenopus tropicalis, followed by Tilapia sp. and Clarias sp. Adult sex-ratio was 1:1. Sloughing of skin and ovipositions occurred in dry season, in the humid enclosure of buttress roots amongst leaf litters. Fecundity ranged from 8 to 14 eggs per female, with a mean of 10 eggs $(S D=1.8)$. The smallest gravid female was $78.2 \mathrm{~cm}$ SVL. Eggs were laid in batches of three to four eggs at a site, in at least two to three different sites. The size of the eggs averaged $3.1 \mathrm{~cm}$ in length, $2.1 \mathrm{~cm}$ in width, and had a fresh weight ranging from 18.2 to $22.1 \mathrm{~g}$. Maternal size influenced significantly the number of eggs produced by female, but not their average size. There was a statistically significant negative correlation between number of eggs and mean egg size. Predators of this snake at the study area were herons and fishermen.
\end{abstract}

\section{Contents}

Abstract

Introduction

Study area

Methods

Results

Morphometry

Food habits

Sex-ratio and reproductive biology

Sloughing cycles

Discussion

Acknowledgements

References

\section{Introduction}

The few species of aquatic snakes of the genus Grayia constitute a systematically problematic group of Colubridae that is endemic to tropical Africa (Boulenger, 1909). They have been considered as belonging to the subfamily Grayini (Meirte, 1992), but also "lycodontines" with some morphological affinities to South American xenodontines (e.g. McDowell, 1987). Although locally abundant, these aquatic snakes are notoriously difficult to catch, and their ecology is known only for a few general and anecdotal comments (e.g. see Cansdale, 1961; Isemonger, 1962; Pitman, 1974; Villiers, 1975).

Grayia smythii (= smithii, cf. Meirte, 1992, for a discussion on its correct name) is one of the commonest water snake species of seasonal rainforest swamps and permanent water bodies of the Niger Delta basin and south-eastern flank of Nigeria (Bütler and Reid, 1986, 1990; Luiselli et al., 1998; Akani et al., 1999). Like other rainforest snakes, its persecution goes on unabated, and there are hardly any conservation considerations (Akani et al., 1999). Moreover, the meat was described as a delicacy by several rural households and may possibly be traded on.

Limited ecological data on Nigerian specimens are available only in Dunger (1971), Butler and Reid (1986, 1990), and in more recent studies by Luiselli and Akani (1999), Akani et al. (1999), and Luiselli et al. (1998).

In view of the significance of Grayia smythii in the ecosystem dynamic of the seasonal rainforest 
swamps (Luiselli et al., 1998), this study was conducted in order to provide basic information on its biometrics, habitat characteristics, food habits, reproduction and behaviour.

\section{Study area}

The data presented here are based on a field study carried out during the wet and dry seasons, from December 1998 to March 2000. The study area (about 30 ha of surface) is a seasonal rainforest swamp located at Rumuosi, approximately $15 \mathrm{~km}$ on the northern flank of Port Harcourt $\left(04^{\circ} 45^{\prime} \mathrm{N}\right.$, $\left.004^{\circ} 01^{\prime} \mathrm{E}\right)$, the capital city of Rivers State, Nigeria. The vegetation is essentially secondary forest, characterized by such flora as Pterocarpus sp., Raphia sp., Triumphetta eriophlebia, Mitragyna stipulosa, etc. which have broad leaves, and grow adventitious roots as the water level rises. On the slightly elevated spots, the trees Triplichiton scleroxylon, Khaya sp., Terminalia superba, Mitragyna ciliata are found. The undergrowth is lush and dominated by pterophytes (ferns), shrubs, herbs, and sedges. Due to the shading effect of the crown, light conditions were similar to twilight even at midday. Another significant feature of the swamp is that the forest floor is interspersed with several natural and man-made ponds of varying depths and surfaces, often bordered by hydrophytes.

The Rumuosi swamp depends exclusively on rainfall during wet season (May-October) for its water supply and has no link at all to other water bodies. Inundation of the swamp usually occurs by July / August, during which an area of over 25 ha may be under water. Floodwater encroaches into neighbouring farmlands causing serious crop damage. The water is lentic, generally shallow but deeper in the ponds, and is brown in colour. By dry season (November-April) over $85 \%$ of the swamp dries out, leaving water only in the deep ponds. Thick cushions of dry leaves are common due to increased leaf abscission in the dry season. The surface of the ponds at this time is covered with green floating macrophytes, including Lemna sp., Azolla sp., Ceratophyllum demersum, Nymphaea lotus, etc. Water temperature, $\mathrm{pH}$, dissolved oxygen, and Total Dissolved Solid (TDS), and Alkalinity, measured in situ, are presented in Table 1.
Table I. Means and Standard Deviation of physico-chemical parameters of the seasonal freshwater swamp at Rumuosi (Rivers State, Nigeria), where the ecology of Grayia smythii has been studied. Ranges are in parentheses.

\begin{tabular}{lcc}
\hline Parameter & $\begin{array}{c}\text { Wet Season } \\
(N=65)\end{array}$ & $\begin{array}{c}\text { Dry Season } \\
(N=57)\end{array}$ \\
\hline Air Temperature $\left({ }^{\circ} \mathrm{C}\right)$ & $25.6 \pm 1.5$ & $30.8 \pm 1.8$ \\
& $(24-29)$ & $(27.6-33)$ \\
Water Temperature $\left({ }^{\circ} \mathrm{C}\right)$ & $25.1 \pm 0.8$ & $28.5 \pm 1.1$ \\
& $(24-26.1)$ & $(26.2-30.4)$ \\
PH & $5.6 \pm 0.9$ & $6.2 \pm 1.3$ \\
& $(4.8-6.6)$ & $(5.0-6.8)$ \\
Electricity $\mu S / \mathrm{cm}$ & $15.7 \pm 5.4$ & $24.7 \pm 6.8$ \\
Conductivity & $(10.0-23.0)$ & $(12.8-30.5)$ \\
Salinity & $0(0)$ & $0(0)$ \\
Transmittance at & $98 \pm 1.3$ & $97 \pm 1.8$ \\
$\quad 420 \mu(\%)$ & $(97.2-99.5)$ & $(96.0-98.9)$ \\
Dissolved Oxygen (mg/l) & $0.5 \pm 0.2$ & $0.5 \pm 0.2$ \\
& $(0-1.0)$ & $(0-1.0)$ \\
TDS (mg/l) & $12.2 \pm 2.5$ & $14.1 \pm 2.0$ \\
& $(10.0-13.1)$ & $(12.0-16.8)$ \\
Total Alkalinity as & & \\
CaCO3 (mg/l) & $14.8 \pm 3.2$ & $16.2 \pm 2.6$ \\
& $(12.0-18.6)$ & $(13.1-19.3)$ \\
\hline
\end{tabular}

Shrimp, leeches, amphibians (Xenopus tropicalis, Ptychadena spp., Hoplobatrachus occipitalis, Bufo maculatus, Bufo regularis, and undetermined Hyperoliidae tree-frogs), fish (families Clariidae, Cichlidae, Malapteruridae, Phractolaemidae, Cyprinodontidae), reptiles (Agama agama, Mabuya affinis, Psammophis cf. phillipsi, Natriciteres variegata, Natriciteres fuliginoides, Gastropyxis smaragdina, Naja nigricollis, Causus maculatus), and small mammals (Crocidura nigeriae, Crocidura poensis, Mus musculoides, Lemniscomys sp., Rattus rattus) are found in the swamp or in the immediate surroundings (Akani and Luiselli, unpublished trapping data). Apart for fishermen (who catch these snakes with no return valves), the major natural predators of Grayia smythii at the study area were herons, that were observed to prey even on adult specimens from the water surface. Nile monitors (Varanus niloticus ornatus) were also observed preying on adult Grayia smythii in other areas of the Niger Delta, and cobras (Naja nigricollis and Naja melanoleuca) also may prey on these snakes as they can forage in water and are known to eat occasionally on snakes (Luiselli and Angelici, 2000). 


\section{Methods}

Samples of Grayia smythii were collected both by traps and by capture, of specimens encountered during standardized routes throughout the study area. Specimens trapped were captured by means of 12 basket traps with no return valves (fishing gears commonly used in the area), set amongst barricades (approximately $1 \mathrm{~m}$ high) that entirely surrounded the swamp perimeter. As already explained, the swamp perimeter varied considerably between seasons. These barricades were made of palm fronds obtained from the Oil palm tree, Elaeis guineensis and reeds. The traps were set for 65 days in the dry season, and for 57 days in the wet season in both shallow and deeper waters. They were set by 8.00 am each day and inspected by the same time the following day. Other sources of the specimens included fishermen's catch, both when the swamp was inundated and when the ponds were bailed in dry season. All captured individuals were taken to the research laboratory at Department of Biological Sciences, Rivers State University of Science and Technology (Port Harcourt), not more than two hours after collection. Morphometric measurements (snout-vent length (SVL), tail length (tL), head length (HD), head width (HW), and body mass were recorded from all the captured specimens. The specimens that had died already were dissected for determination of sex, stomach contents, fecundity, egg sizes, etc.

Statistical analyses were done by a SPSS and a STATISTICA for Windows PC packages, with all tests being two tailed and alpha set at 5\%. Means are followed by \pm one Standard Deviation.

\section{Results}

\section{Morphometry}

SVLs were measured in 16 adult males and 17 adult females from the study population. Females averaged slightly longer SVL than males $(x=74.48 \pm$ $13.23 \mathrm{~cm}$ versus $69.35 \pm 11.62 \mathrm{~cm})$, but the intersexual differences did not attain statistical significance $(t=1.18, \mathrm{df}=31, P=0.247)$. Moreover,* although SVL and tL were highly correlated (in the two sexes, at least $r>0.74, P<0.00001$ ), the

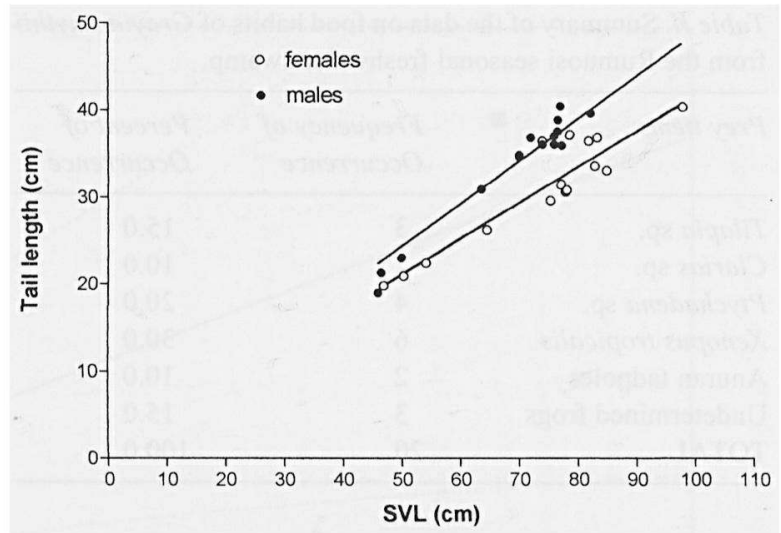

Fig. 1. Correlation between body length (SVL, $\mathrm{cm}$ ) and tail length in Grayia smythii from the study area. For statistical details, see text.

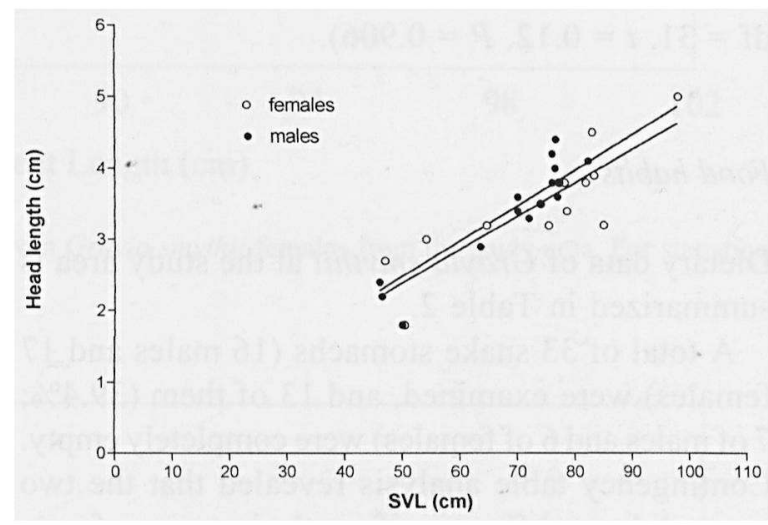

Fig. 2. Correlation between body length (SVL, cm) and head length in Grayia smythii from the study area. For statistical details, see text.

males differed significantly from the females in terms of body proportions (Fig. 1). Single-factor analysis of covariance (with sex as the factor, and SVL as the covariate) showed that for the same body length, female Grayia smythii had shorter tails than males (ANCOVA on ordinate intercepts: $F=$ $19.201, \mathrm{DFn}=1, \mathrm{DFd}=27, P<0.0001)$. Indeed, the two sexes differed significantly in terms of mean tL / SVL ratio (males: $x=0.485 \pm 0.019, N=15$, range 0.458-0.525; females: $x=0.413 \pm 0.023, N$ $=16$, range $0.388-0.472$; intersexual differences significant at $P<0.000001$, Student $t$-test with $\mathrm{df}$ $=29$ ). On the other hand, the two sexes were similar in terms of head size relative to SVL (singlefactor ANCOVA with sex as the factor and SVL as the covariate: $F=3.217$, DFn $=1, \mathrm{DFd}=27, P$ $=0.834$; Fig. 2). In fact the mean HD / SVL ratios 
Table II. Summary of the data on food habits of Grayia smythil from the Rumuosi seasonal freshwater swamp.

\begin{tabular}{lcc}
\hline Prey items & $\begin{array}{l}\text { Frequency of } \\
\text { Occurrence }\end{array}$ & $\begin{array}{l}\text { Percent of } \\
\text { Occurrence }\end{array}$ \\
\hline Tilapia sp. & 3 & 15.0 \\
Clarias sp. & 2 & 10.0 \\
Ptychadena sp. & 4 & 20.0 \\
Xenopus tropicalis & 6 & 30.0 \\
Anuran tadpoles & 2 & 10.0 \\
Undetermined frogs & 3 & 15.0 \\
TOTAL & 20. & 100.0 \\
\hline
\end{tabular}

were almost identical in the two sexes (males: $x=$ $0.049 \pm 0.0031, N=16$, range $0.046-0.057$; females: $x=0.049 \pm 0.006, N=17$, range 0.038 0.063 ; intersexual differences: Student $t$-test with $\mathrm{df}=31, t=0.12, P=0.906$ ).

\section{Food habits}

Dietary data of Grayia smythii at the study area is summarized in Table 2.

A total of 33 snake stomachs (16 males and 17 females) were examined, and 13 of them $(39.4 \%$; 7 of males and 6 of females) were completely empty. Contingency table analysis revealed that the two sexes did not differ significantly in terms of proportion of specimens with prey in stomachs $(P>$ $0.3)$. Five of 11 gravid females had food in the stomach. The proportion of gravid females containing food $(45.4 \%)$ was lower than that of nongravid females $(100 \%, N=6)$, and suggests a reduction in the feeding rates of the specimens with eggs.

Grayia smythii was found to prey exclusively upon fish (25\%) and anurans, either tadpoles or metamorphs (75\%). The major fish prey was Tilapia sp. followed by Clarias sp., and the major amphibian prey was Xenopus tropicalis, which is abundant in the swamp. Dietary composition of the two sexes was similar $\left(\chi^{2}\right.$ test, $P>0.6$ ). It was observed that all preys found in snake stomachs were oriented with their heads towards the posterior direction of the snake, which implies that Grayia swallows its prey's head first. With this habit of swallowing, it is clear that the dorsal spines of the cichlid fish or the pectoral spine of the clariid fish are forced to fold as they are being swallowed, which helps the ingestion process. The largest prey ingested was a Tilapia sp. which measured 11.3 $\mathrm{cm}$ in total length, and $3.5 \mathrm{~cm}$ wide.

Although there were abundant aquatic insects, leech, and shrimps in the ponds, none of these species were found in any snakes' stomach.

\section{Sex-ratio and reproductive biology}

Adult sex-ratio (16 males and 17 females) was found to be $1: 1$ (binomial test, $P>0.9$ ).

The bulk of the females caught in dry season (73.3\%, total $N=15)$ were gravid. Females with eggs were captured in December $(N=1)$, January $(N=1)$, February $(N=7)$, and March $(N=2)$. The mean SVL of the gravid females was 81.77 \pm $6.02 \mathrm{~cm}(N=11$, range $77.2-98 \mathrm{~cm})$, and their mean body mass was $429.0 \pm 146.88 \mathrm{~g}$ (range 325 $800 \mathrm{~g}$ ). The average fecundity was $10.0 \pm 1.8 \mathrm{eggs}$ per female (range 8-14). The eggs, when in the gonad, were elliptical in shape and yellowish to orange in colour. The smallest female to produce eggs measured $77.2 \mathrm{~cm} \mathrm{SVL}$ and $108.6 \mathrm{~cm}$ total length, weighed $325 \mathrm{~g}$, and had 9 well developed eggs in the ovary.

Eggs were laid by end of March in the enclosure of buttress roots amongst leaf litters close to the pond ( $N=8$ clutches observed). In practice, the eggs were deposited in small burrows on sandy soil, and were covered by abundant leaf litter. In all cases observed $(N=8)$, they were laid in batches of three to four eggs at a site, which means that a female may oviposit its eggs in at least two to three different sites (given that the average clutch size of each female was approximately 10 eggs. The size of the eggs averaged $3.1 \mathrm{~cm}$ in length, $2.1 \mathrm{~cm}$ in width, and had a fresh weight ranging from 18.2 to $22.1 \mathrm{~g}$.

Grayia smythii oviposition period coincides with the hottest period in the swamp (Table I), and it is likely that increase in temperature would enhance hatchability of the eggs.

Maternal size (SVL) influenced significantly the number of eggs produced by female $(r=0.66, N$ $=11, P<0.01$; regression equation: number of eggs $=-6.96+0.204 \times$ SVL; Fig. 3), but not their 


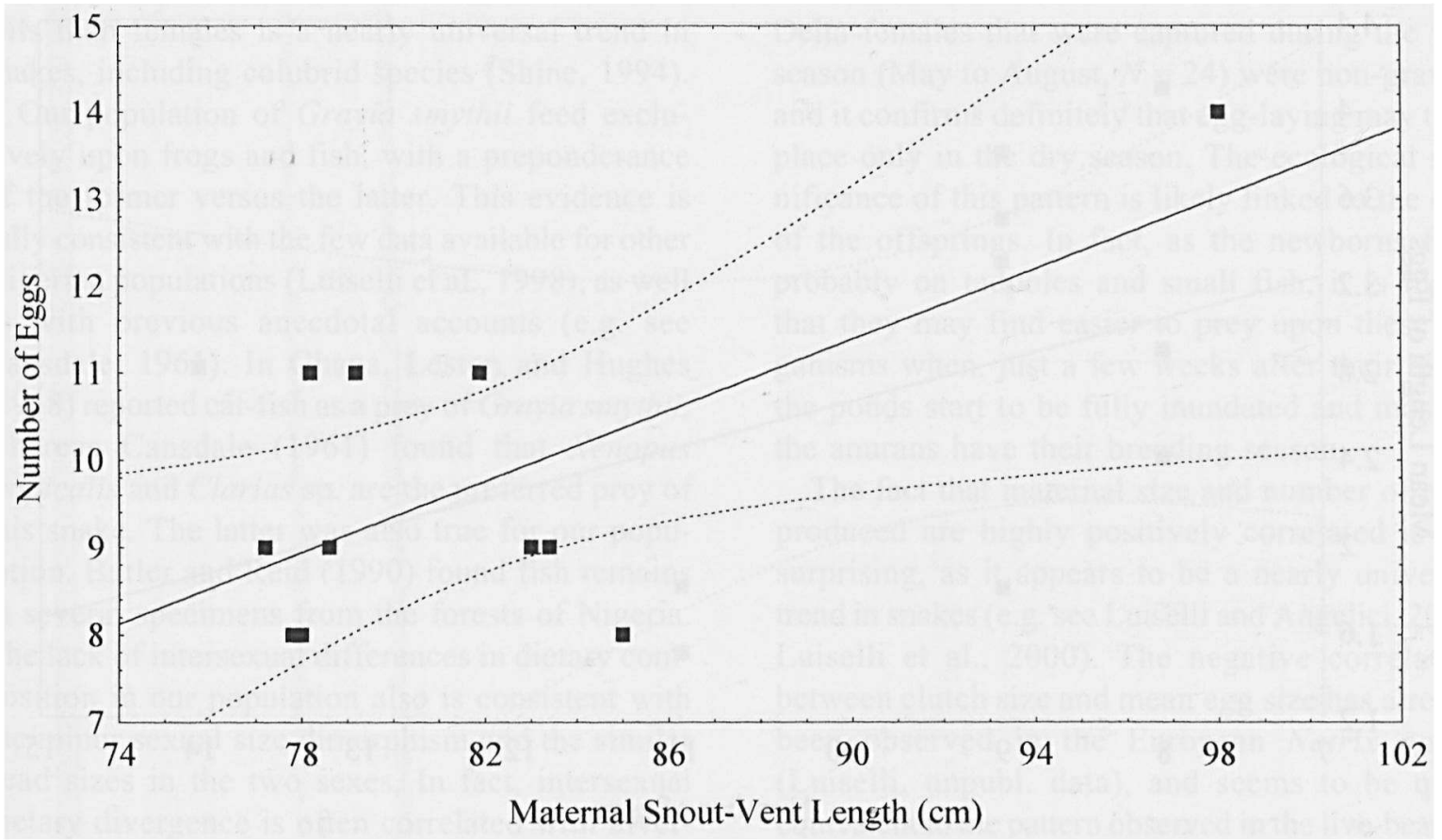

Fig. 3. Correlation between maternal size and number of eggs in eleven Grayia smythii females from the study area. For statistical details, see text.

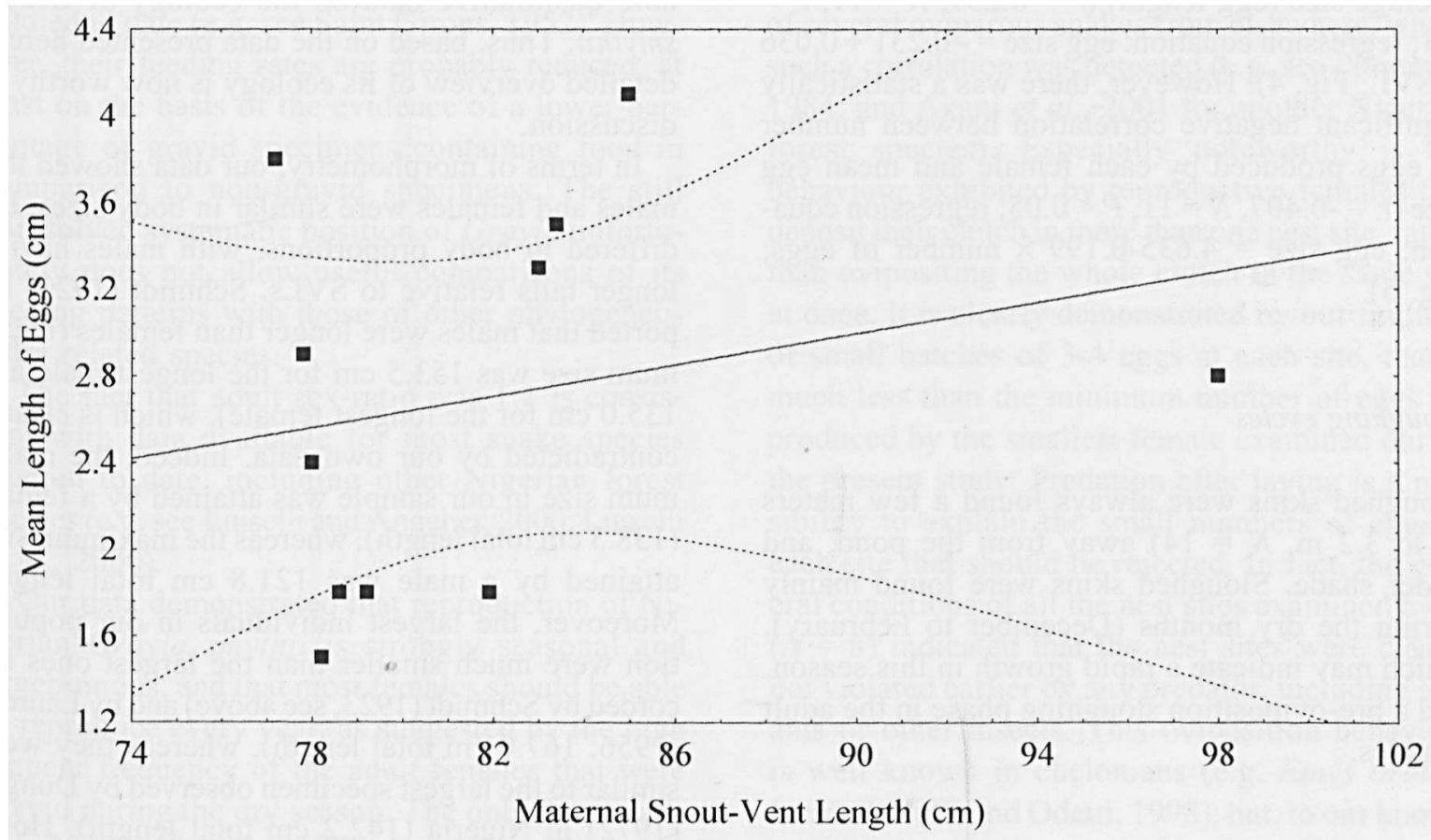

Fig. 4. Correlation between maternal size and mean egg size in eleven Grayia smythii females from the study area. For statistical details, see text. 


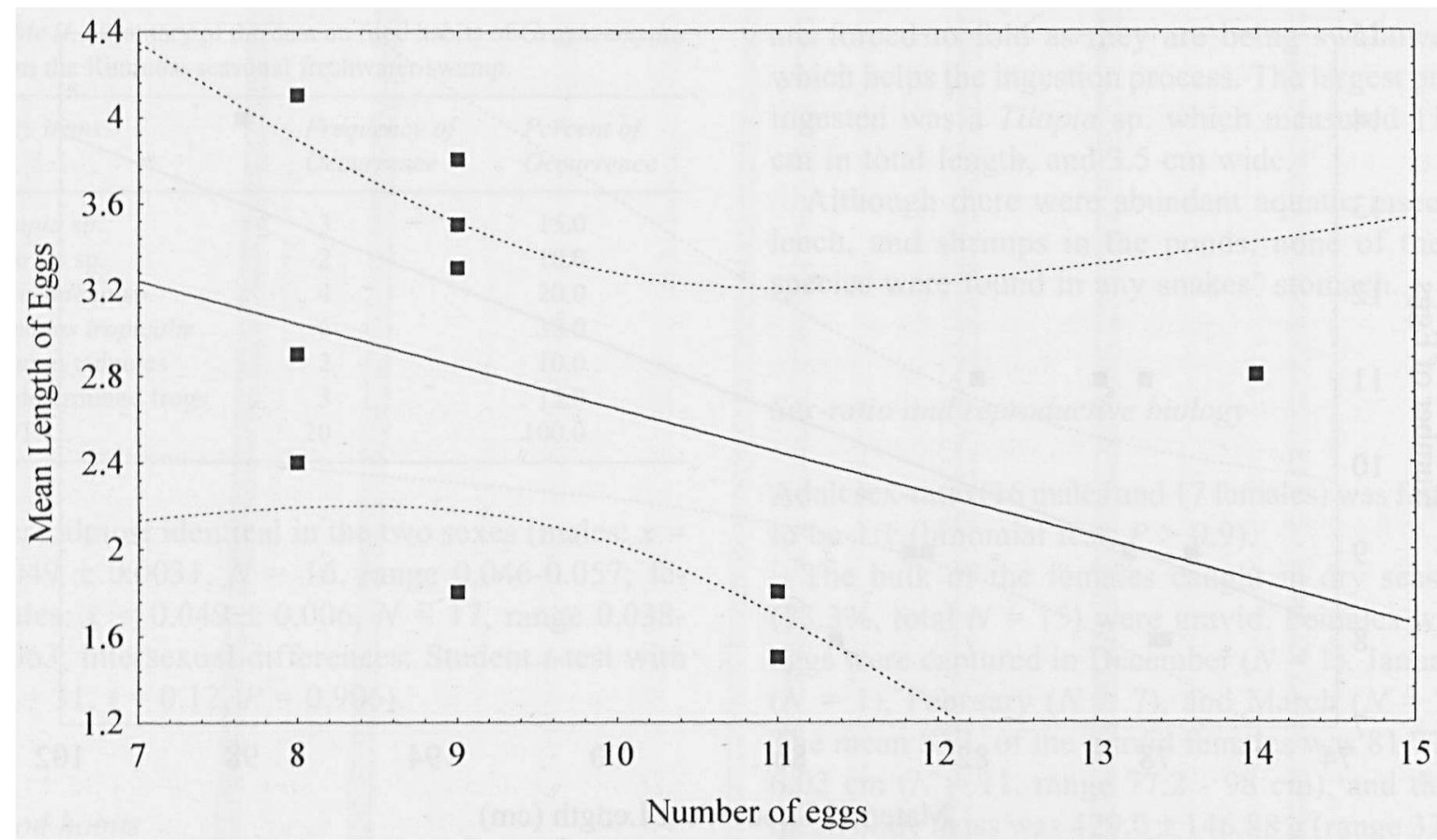

Fig. 5. Correlation between number of eggs produced by female and mean egg size in eleven Grayia smythii females from the study area. For statistical details, see text.

average size (egg length) $(r=0.237, N=11, P>$ 0.1 ; regression equation: egg size $=-0.231+0.036$ $\times$ SVL; Fig. 4). However, there was a statistically significant negative correlation between number of eggs produced by each female and mean egg size $(r=-0.407, N=11, P<0.05$; regression equation: egg size $=4.635-0.199 \times$ number of eggs; Fig. 5).

\section{Sloughing cycles}

Sloughed skins were always found a few meters (0 to $3.2 \mathrm{~m}, N=14$ ) away from the pond, and under shade. Sloughed skins were found mainly during the dry months (December to February), which may indicate a rapid growth in this season, and a pre-oviposition sloughing phase in the adult females.

\section{Discussion}

Although based on a relatively small sample size, our study has probably added significantly to avail- able quantitative data on the ecology of Grayia smythii. Thus, based on the data presented here, a detailed overview of its ecology is now worthy of discussion.

In terms of morphometry, our data showed that males and females were similar in body sizes, but differed in body proportions, with males having longer tails relative to SVLs. Schmidt (1923) reported that males were longer than females (maximum size was $153.5 \mathrm{~cm}$ for the longest male and $135.0 \mathrm{~cm}$ for the longest female), which is clearly contradicted by our own data. Indeed, the maximum size in our sample was attained by a female (138.3 cm total length), whereas the maximum size attained by a male was $121.8 \mathrm{~cm}$ total length. Moreover, the largest individuals in our population were much smaller than the largest ones recorded by Schmidt (1923, see above) and by Laurent (1956: $167.0 \mathrm{~cm}$ total length), whereas they were similar to the largest specimen observed by Dunger (1972) in Nigeria (142.2 cm total length). However, the largest specimen captured by Luiselli et al. (1998) in Eket (Akwa-Ibom State, Nigeria) exceeded $160 \mathrm{~cm}$ in total length.

The fact that male Grayia smythii had longer 
tails than females is a nearly universal trend in snakes, including colubrid species (Shine, 1994).

Our population of Grayia smythii feed exclusively upon frogs and fish; with a preponderance of the former versus the latter. This evidence is fully consistent with the few data available for other Nigerian populations (Luiselli et al., 1998), as well as with previous anecdotal accounts (e.g. see Cansdale, 1961). In Ghana, Leston and Hughes (1968) reported cat-fish as a prey of Grayia smythii, whereas Cansdale (1961) found that Xenopus tropicalis and Clarias sp. are the preferred prey of this snake. The latter was also true for our population. Butler and Reid (1990) found fish remains in several specimens from the forests of Nigeria. The lack of intersexual differences in dietary composition in our population also is consistent with the minor sexual size dimorphism and the similar head sizes in the two sexes. In fact, intersexual dietary divergence is often correlated with divergence in absolute body size or in head size (Shine, $1986,1991)$. It is noteworthy that the adult females continued to forage also during pregnancy, contrary to what happens in many species of snakes studied to date (e.g. see Saint Girons, 1952). However, their feeding rates are probably reduced, at least on the basis of the evidence of a lower percentage of gravid specimens containing food in comparison to non-gravid specimens. The still unresolved systematic position of Grayia unfortunately does not allow useful comparisons of its feeding patterns with those of other phylogenetically related species.

The fact that adult sex-ratio was $1: 1$ is consistent with data available for most snake species studied to date, including other Nigerian forest species (e.g. see Luiselli and Angelici, 2000; Luiselli et al., 2000).

Our data demonstrated that reproduction of Nígerian Grayia smythii is strongly seasonal and synchronous, and that most females should be able to reproduce every year, as suggested by the high percent frequency of the adult females that were gravid during the dry season. The only data available for Nigerian Grayia smythii also suggests that egg-laying should occur in dry season (oviposition of a single captive specimen on 7 December 1969, see Butler and Reid, 1990). The adult Niger
Delta females that were captured during the wet season (May to August, $N=24$ ) were non-gravid, and it confirms definitely that egg-laying may take place only in the dry season. The ecological significance of this pattern is likely linked to the diet of the offsprings. In fact, as the newborns feed probably on tadpoles and small fish, it is likely that they may find easier to prey upon these organisms when, just a few weeks after their birth, the ponds start to be fully inundated and most of the anurans have their breeding season.

The fact that maternal size and number of eggs produced are highly positively correlated is not surprising, as it appears to be a nearly universal trend in snakes (e.g. see Luiselli and Angelici, 2000; Luiselli et al., 2000). The negative correlation between clutch size and mean egg size has already been observed in the European Natrix natrix (Luiselli, unpubl. data), and seems to be quite equivalent to the pattern observed in the live-bearing Thamnophis buitleri, where larger clutches produced smaller young (Ford and Killebrew, 1983). However, the lack of positive correlation between female size and mean egg size does not mirror data of several oviparous snakes from elsewhere, where such a correlation was detected (e.g. see Plummer, 1984; and Akani et al., 2001 for another Nigerian forest species). Especially noteworthy is the behaviour exhibited by reproductive females that deposit their clutch in more than one nest site, rather than ovipositing the whole clutch in the same site at once. It is clearly demonstrated by our findings of small batches of 3-4 eggs at each site, that is much less than the minimum number of eggs (8) produced by the smallest female examined during the present study. Predation after laying is a possibility to explain the small numbers of eggs at each site that should be rejected. In fact, the general conditions of all the nest sites examined by us $(N=8)$ indicated that the nest sites were clearly not violated earlier by any predator, including also ants or other insects. This oviposition behaviour is well known in chelonians (e.g. Emys orbicularis, cf. Zuffi and Odetti, 1998), but, to our knowledge, has never been recorded before in free-ranging snakes. Although very preliminary, our findings suggest that this is likely an important reproductive strategy of Grayia smythii, possibly linked to 
the need to reduce egg mortality due to predation (by monitor lizards, other snakes, birds, mongooses, etc) and to desiccation in dry season.

\section{Acknowledgements}

This research study was financially supported by Aquater S.p.A., Ecosystem s.r.l., the Institute Demetra, T.S.K.J. Nigeria Itd (Lagos and Port Harcourt) and, indirectly, by ENI Group environmental Department. The Federal Department of Forestry, Port Harcourt, is thanked for having permitted to capture the specimens studied in this paper. Critical reviews of this manuscript were provided by two anonymous referees, Dr Francesco M. Angelici, Dr Dario Capizzi, Dr Ernesto Filippi, Dr Zena Tooze, and Dr Massimo Capula. Dr Joe Butler provided us with some crucial references, and Dr Zena Tooze polished the English style.

\section{References}

Akani GC, Luiselli L, Politano E. 1999. Ecological and conservation considerations on the reptile fauna of the eastern Niger Delta (Nigeria). Herpetozoa 11:14I-153.

Akani GC, Luiselli L, Tooze Z. 2001. Philothamnus heterodermus. Reproduction. Herpetol. Review 32: in press.

Boulenger GA. 1909. On the ophidian genus Grayia. Proc. Zool. Soc. Lond. 1909: 944-952.

Butler JA, Reid J. 1986. Habitat preferences of snakes in the Southern Cross River State, Nigeria. In: Rocek, Z., ed. Studies in herpetology. Charles University, Prague, pp. 483-488.

Butler JA, Reid J. 1990. Records of snakes from Nigeria. Nigerian Field 55: 19-40.

Cansdale GS. 1961. West African Snakes, London: Longmans.

Dunger GT. 1971. The snakes of Nigeria. Part 3. The harmless water and marsh snakes of Nigeria. Nigerian Field 36: 21-38.

Ford NB, Killebrew DW. 1983. Reproductive tactics and female body size of Butler's garter snake (Thamnophis butleri). J. Herpetol. 17: 271-275.

Isemonger RM. 1962. Snakes of Africa. Cape Town: Books of Africa.

Laurent RF. 1956. Contribution à l'Herpétologie de la Région des Grands Lacs de 1"Afrique centrale. Ann. Mus. Congo Belge, Sér. 8, Sci. Zool. 48: 1-300.

Leston P, Hughes B. 1968. The snakes of Tafo, a forest cocoa-farm locality in Ghana. Bull. Inst. Fund. Afr. Noire 30: 737-770.
Luiselli L, Akani GC. 1999. Habitats of snakes in the rainforests of Eket (Akwa-Ibom State, south-eastern Nigeria). Herpetozoa 11: 99-107.

Luiselli L, Akani GC, Capizzi D. 1998. Food resource partitioning of a community of snakes in a swamp-

rainforest of south-eastern Nigeria. $J$. Zool. Lond. 246: 125133.

Luiselli L, Angelici FM. 2000. Ecological relationships in two Afrotropical cobra species (Naja melanoleuca and Naja

nigricollis). Canad. J. Zool. 78: 191-198.

Luiselli L, Angeliei FM, Akani GC. 2000. Large elapids and arboreality: the ecology of Jameson's green mamba

(Dendroaspis jamesoni) in an Afrotropical forested region. Contrib. Zool. 69: 147-155.

McDowell SB. 1987. Systematics. In: Seigel, R.A., Collins, J.T., and Novak, S.S., eds. Snakes, ecology and evolutionary biology. MacMillan, New York, pp. 3-50.

Meirte D. 1992. Cles de determination des serpents d'Afrique. Ann. Sci. Zool. Mus. Royal Afr. Centr, Tervuren 267:1152.

Pitman CRS. 1974. A guide to the snakes of Uganda. Revised Edition. Wheldon \& Wesley Ltd., Codicote, pp. XXII +290.

Plummer MV. 1984. Female reproduction in an Arkansas population of rough green snakes (Opheodrys aestivus). In: Seígel RA, Hunt LE, Knight JL, Malaret L, Zuschlag $\mathrm{N}$, eds. Vertebrate Ecology and Systematics: A Tribute to Henry S. Fitch. Univ. Kansas Mus. Nat. Hist. Spec. Publ. 10: 105-113.

Saìnt Girons H. 1952. Ecologie et éthologie des Vipères de France, Ann. Sci. Nat. Zool. Paris 14*263-343.

Schmidt KP. 1923. Contributions to the herpetology of Belgian Congo based on the collection of the American Museum Congo expedition, Part II. Snakes, Bull. Amer. Mus. Nat. Hist. 49: 1-146, +22 plates.

Shine R. 1986. Sexual differences in morphology and niche utilization in an aquatic snake, Acrochordus arafurae. Oecologia 69: 260-267.

Shine R. 1991. Intersexual dietary divergence and the evolution of sexual dimorphism in snakes. Am. Nat. 138: 103-122.

Shine R. 1994. Sexual size dimorphism in snakes revisited. Copela 1994: 326-346.

Zuffi MAL, Odetti F. 1998. Double egg-deposition in the European pond turtle, Emys orbicularis, from central Italy. Ital. J. Zool. 65: 187-189.

Villiers A. 1975. Les Serpents de l'Ouest Africain. Initiations Africaìnes, I.F.A.N.: Dakar, 1-195.

Accepted: 9 January 2001 